\title{
Article \\ Prediction of B20 Storage Tank Precipitate Removal Based on Biodiesel Monoglyceride Content
}

\author{
Misri Gozan ${ }^{1, *}$, Imam Paryanto ${ }^{1}$, Muhammad Arif Darmawan ${ }^{1}$, Muhammad Sahlan ${ }^{1}{ }^{(0,}$, Heri Hermansyah ${ }^{1}$, \\ Eriawan Rismana ${ }^{2}$, Alfan Danny Arbianto ${ }^{2}$, Tirto Prakoso ${ }^{3} \mathbb{C}$, Mohamed Kheireddine Aroua ${ }^{4}(\mathbb{D}$ \\ and Patrick Cognet ${ }^{5}$
}

\section{check for}

updates

Citation: Gozan, M.; Paryanto, I.;

Darmawan, M.A.; Sahlan, M.;

Hermansyah, H.; Rismana, E.;

Arbianto, A.D.; Prakoso, T.; Aroua,

M.K.; Cognet, P. Prediction of B20

Storage Tank Precipitate Removal

Based on Biodiesel Monoglyceride

Content. ChemEngineering 2022, 6, 7 .

https://doi.org/10.3390/

chemengineering6010007

Academic Editor: Andrew S. Paluch

Received: 1 November 2021

Accepted: 7 January 2022

Published: 13 January 2022

Publisher's Note: MDPI stays neutral with regard to jurisdictional claims in published maps and institutional affiliations.

Copyright: (c) 2022 by the authors. Licensee MDPI, Basel, Switzerland. This article is an open access article distributed under the terms and conditions of the Creative Commons Attribution (CC BY) license (https:/ / creativecommons.org/licenses/by/ $4.0 /)$.
1 Department of Chemical Engineering, Faculty of Engineering, Universitas Indonesia, Depok 16424, West Java, Indonesia; imam.paryanto@bppt.go.id (I.P.); muhammad.arif33@sci.ui.ac.id (M.A.D.); sahlan@che.ui.ac.id (M.S.); heri@che.ui.ac.id (H.H.)

2 Agency for the Assessment and Application of Technology, Jakarta 15314, West Java, Indonesia; eriawan.rismana@bppt.go.id (E.R.); alfan.danny@bppt.go.id (A.D.A.)

3 School of Chemical Engineering, Faculty of Industrial Engineering, Bandung Institute of Technology, Jalan Ganesha No.10, Bandung 40116, West Java, Indonesia; tirto@che.itb.ac.id

4 Centre for Carbon Dioxide Capture and Utilization (CCDCU), School of Science and Technology, Sunway University, No. 5, Jalan Universiti, Bandar Sunway, Petaling Jaya 47500, Malaysia; kheireddinea@sunway.edu.my

5 Laboratoire de Génie Chimique, Université de Toulouse, CNRS, INPT, UPS, F-31432 Toulouse, France; patrick.cognet@ensiacet.fr

* Correspondence: mgozan@ui.ac.id

\begin{abstract}
Precipitate in B20 fuel stored in storage tanks can accumulate at the bottom level of the tank and affect the fuel filter, clogging in the fuel distribution and engine system. This study examines the precipitate formation prediction in B20 fuel based on the monoglyceride content in biodiesel. This research used a modified CSFT method of ASTM D7501 for the precipitation test. Monopalmitin was added to biodiesel with a variation of monoglyceride content. Each biodiesel sample was then blended with petroleum diesel fuel to produce two groups of samples. Each sample was separately soaked in the cooling chamber at constant and room temperature for 21 days. The bottom layer of each B20 fuel sample stored in the measuring cylinder was then pipetted and filtered, washed with petro-ether, vacuum-dried, and weighed for a constant amount of precipitate retained on the filter. The simulation results show that the ratios between the amount of collected precipitate at the bottom layer of the 2-liter measuring cylinder and the total amount of collected precipitate for the 2-liter measuring cylinder increased with the monoglyceride content biodiesel. This ratio was used to predict the amount of accumulated sludge for a given volume of B20 fuel loaded into the storage tank. This study shows the effect of monoglyceride content on the precipitation behaviour in the storage tank concerning general tank storage dimension parameters and B20 loading frequency. This approach can be applied to estimate the sludge removal frequency for biodiesel storage.
\end{abstract}

Keywords: biodiesel; B20; monoglyceride; precipitation; fuel handling

\section{Introduction}

Biodiesel has been mainly used as a substitute fuel in blended fuels. It has demonstrated better performance in engines due to several advantages compared to the conventional petrodiesel fuel, such as a higher flash point, improved lubricity, lower toxicity, lower sulfur content, and biodegradability [1-4]. Biodiesel, also known as fatty acid methyl ester (FAME), is a renewable fuel produced by esterification or trans-esterification reactions of fatty acids (plant or animal oil). The trans-esterification reaction for biodiesel production is reversible. One mole of triglyceride reacts with three moles of alcohol (a molar ratio of methanol to vegetable oil of 3:1) to form one mole of glycerol and three moles of the respective fatty acid alkyl esters [2]. The conversion of oils to biodiesel is considerably 
high in normal optimum conditions so that the trace of unreacted glycerides is very low. However, unreacted glyceride impurities—especially monoglycerides—even in very low amounts, can affect biodiesel properties significantly $[5,6]$. The biodiesel production process can produce impurities such as saturated monoglycerides (SMG), precipitating at the low-temperature condition. This is due to the high final melting temperature (FMT) or melting point of SMG and will form solid deposits above cloud point (CP) [7-10]. Biodiesel in blended fuel is limited by its poor cold flow characteristics [11-13]. The problem of low-temperature biodiesel performance relates to the formation of precipitate that could cause filter clogging problems $[14,15]$.

Limited information is available on the mechanism of this precipitate formation. Fortunato et al. [16] approach the precipitate formation through the occurrence of biodiesel fuel autooxidation during storage. This autooxidation forms precursor deposits in the liquid phase. The precursor then undergoes either adsorption onto the tank's surface or further agglomerations. Precursor agglomeration occurs with the mechanism of oil-oil emulsion and coalescence to form a liquid film deposit on the surface. The increase in polarity of this emulsion accelerates the deposit forming. This agglomeration approach may also happen on the filter surface during filter clogging.

There are available tests for the assessment of the precipitation in biodiesel-petroleum diesel blended fuel and its clogging effects on fuel filters; namely, ASTM D 7501 for cold soak filtration test (CSFT) $[17,18]$ and ASTM D 2068 for filter blocking test (FBT) $[19,20]$. CSFT combines cold-soaking steps (in terms of soaking temperatures and time) and filterability for determining fuel filter clogging tendency. FBT is a method for determining the fuel filter blocking tendency and filterability of middle distillate fuel oils and non-petroleum liquid fuels such as biodiesel. The fuel users demand good cleanliness of the fuel. Previous studies were conducted for cold soaking filtration test of B10, B20, and B30 for varied conditions of soaking and type of monoglyceride [21-26] in palm oil-based biodiesel, and their results indicated that the formation of precipitate was influenced by monoglyceride content in B100, percentage of B100 in BXX, and soaking temperature conditions.

Biodiesel is generally utilized in blended fuel with petroleum diesel fuel or called BXX, where XX is denoted as the percentage of biodiesel in the blended fuel. Many countries have already applied different portions of biodiesel in the blended fuel [27]. Biodiesel in Indonesia has been mandated and marketed with small quantities $(2.5 \%-\mathrm{vol})$ in blended fuel since 2006. Then it has been gradually increased to $20 \%$-vol biodiesel (B20) since early 2016. One of the challenges in the B20 implementation is to maintain the quality of B20 fuel during storage and handling [28,29]. B20 fuel can cause accumulated sludge to be stored in large quantities and for a long storage period. Scheduled loading of new B20 fuel in large volumes to the storage tanks also means adding some potential precipitates in the loaded B20 fuel. The added precipitates could accumulate in the bottom layer of the storage tank as sludge. As mentioned above, there are some methods to predict the clogging in the filter. Yet, although precipitation is a common problem encountered in blended biodiesel storage, there is very limited information on how to predict how fast the tank bottom sludge formed. This study proposed an approach for estimating the precipitation schedule based on monoglyceride content with various general tank storage dimension parameters and B20 loading frequency.

\section{Materials and Methods}

\subsection{Fuel Preparation and Analysis}

B20 fuel used in the study was produced by blending $80 \%$-vol petroleum diesel fuel (B0) and 20\%-vol palm oil-based biodiesel (B100). Petroleum diesel fuel (B0) used in the study was from PT Pertamina, and the distilled palm oil-based biodiesel (B100) sample was supplied by PT Wilmar Nabati Indonesia in Gresik East Java and had a monoglyceride content of $0.174 \%$-mass as in the CoA (Certificate of Analysis). Biodiesel was analyzed for related quality parameters according to SNI 7182:2015 [30]. Monopalmitin was used to vary monoglyceride content in biodiesel for test purposes so that its MG contents reached 0.4, 
0.6 , and $0.8 \mathrm{wt} \%$, respectively, before blending. Monopalmitin was obtained from Tokyo Chemical Industry (TCI) Japan, with specifications of melting point 73.0 to $77.0^{\circ} \mathrm{C}$ and purity $>95 \%$ (GC). The monoglyceride contents in biodiesel samples were then determined according to ASTM D6584 [31] with gas chromatography Perkin-Elmer Clarus equipped with a flame ionization detector (GC-FID), using an Elite 5-HT column (30 $\mathrm{m}$ in length, with $0.32 \mathrm{~mm}$ internal diameter, and $0.1 \mu \mathrm{m}$ film thickness) and a hydrogen gas carrier.

Petrodiesel fuel (B0) was filtered to remove the residue before blending with B20 so that only impurities from B100 could be considered to influence the filter clogging in the B20 precipitation test. B20 samples were prepared by blending B0 and B100 in an 80:20 volume ratio to produce B20. B20 samples were analyzed for several related quality parameters. For comparison, the B20 in the market, known as Biosolar, was also included in the test.

\subsection{Precipitation Test}

The purpose of the precipitation test for B20 fuel was to determine the amount of the collected precipitate for a certain value of monoglyceride content in B100 fuel at varied soaking temperature conditions. The precipitation test applied modified ASTM D 7501 for cold soak filtration testing (CSFT) [17,18]. Two tests were conducted to measure the predicted sludge caused by accumulated precipitation of monoglyceride. The first test was performed by placing $100 \mathrm{~mL}$ of each B20 sample in a closed $100 \mathrm{~mL}$-separating funnel. The blank test using B0 was also conducted by filtering B0 through same size filter paper without soaking. The samples were then placed in the refrigerators at constant, controlled temperatures of 15,20 , and $25^{\circ} \mathrm{C}$ as well as at room temperatures $\left(24-30^{\circ} \mathrm{C}\right)$. After 21 days of soaking, each sample was vacuum-filtered through a $0.8 \mu \mathrm{m}$ filter paper. Cellulose acetate membrane filters used to filter $\mathrm{B} 20$ fuel were Sartorious ${ }^{\mathrm{TM}}$ with the specification of diameter $47 \mathrm{~mm}$ and particle retention $0.8 \mu \mathrm{m}$. Precipitate retained on the filter paper was then washed with petro-ether and dried under vacuum conditions, then its weight was measured. Petroleum ether from Merck was used to wash precipitate so that only monoglyceride in the precipitate remained on the filter.

The second test poured 2 liters of each B20 sample into a pair of closed 2 liter-measuring cylinders. All samples were then placed in the refrigerators, with the constant controlled temperatures of 15,20 , and $25^{\circ} \mathrm{C}$ as well as room temperatures $\left(24-30^{\circ} \mathrm{C}\right)$. After 21 days of soaking, for the same pair of B20 samples but using the first sample in a 2 liter-measuring cylinder, a $100 \mathrm{~mL}$-sample of B20 was taken at the bottom layer cylinder vacuum-filtered through a $0.8 \mu \mathrm{m}$ filter paper. Then, using the second pair of B20 samples in a 2-liter measuring cylinder, all 2-liter samples of B20 were vacuum-filtered through $0.8 \mu \mathrm{m}$ filter paper. All precipitate retained on each filter paper was then washed with petro-ether and dried with vacuum condition, and then its weight was measured.

\subsection{Calculation of Estimated Sludge of B20 and Schedule for Sludge Removal}

In this study, to simulate the removal schedule of sludge accumulated at the bottom layer of the tank, some variations regarding the B20 storage tank conditions were made in terms of fuel storage tank capacity $\left(50,100\right.$, and $\left.200 \mathrm{~m}^{3}\right)$, 'fresh' B20 fuel loading volume $\left(30,75\right.$, or $\left.140 \mathrm{~m}^{3}\right)$, and frequency (every $2,4,3,6,7$, or 14 days); the dimension of storage tanks (i.e., H/D ratio of 1 or 2); and fuel discharge/outlet pipe height (50 or $100 \mathrm{~mm}$ ), as shown in Figure 1 and Table 1. The storage tank capacities used in the simulation were varied at 50,100, and $200 \mathrm{~m}^{3}$, based on the actual fuel storage tanks used in mining industries. The minimum B20 stocks left in the storage tanks were 40, 25, and 30\%-vol, respectively, and after having reached the minimum stock level, 'fresh' B20 fuel was loaded into the storage tank. 

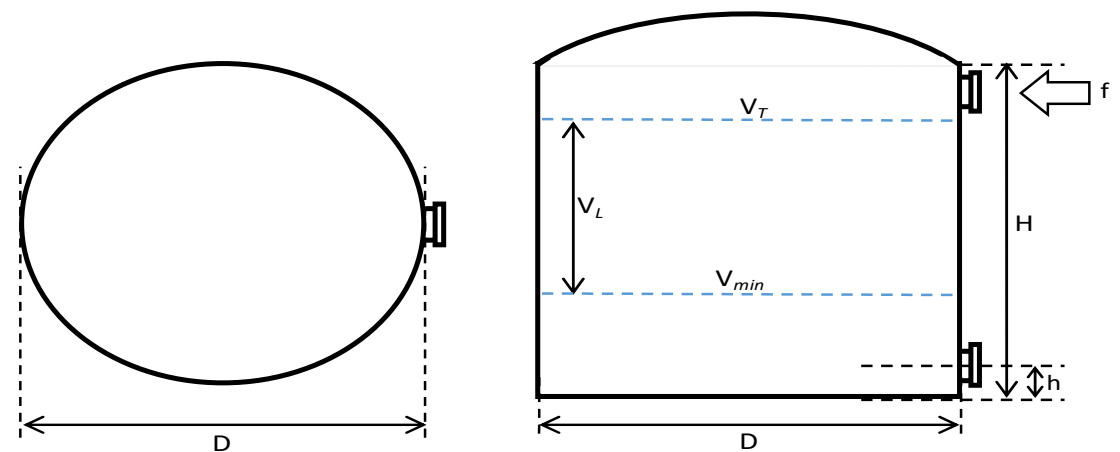

Figure 1. B20 fuel storage tank with variation in storage capacity (VT), dimensions (H/D ratio), discharge piping level (h), the volume of minimum fuel stock (Vmin), and 'fresh' B20 fuel loaded into the tank (VL).

All steps of the experiment are depicted in a flowchart, as shown in Figure 2.

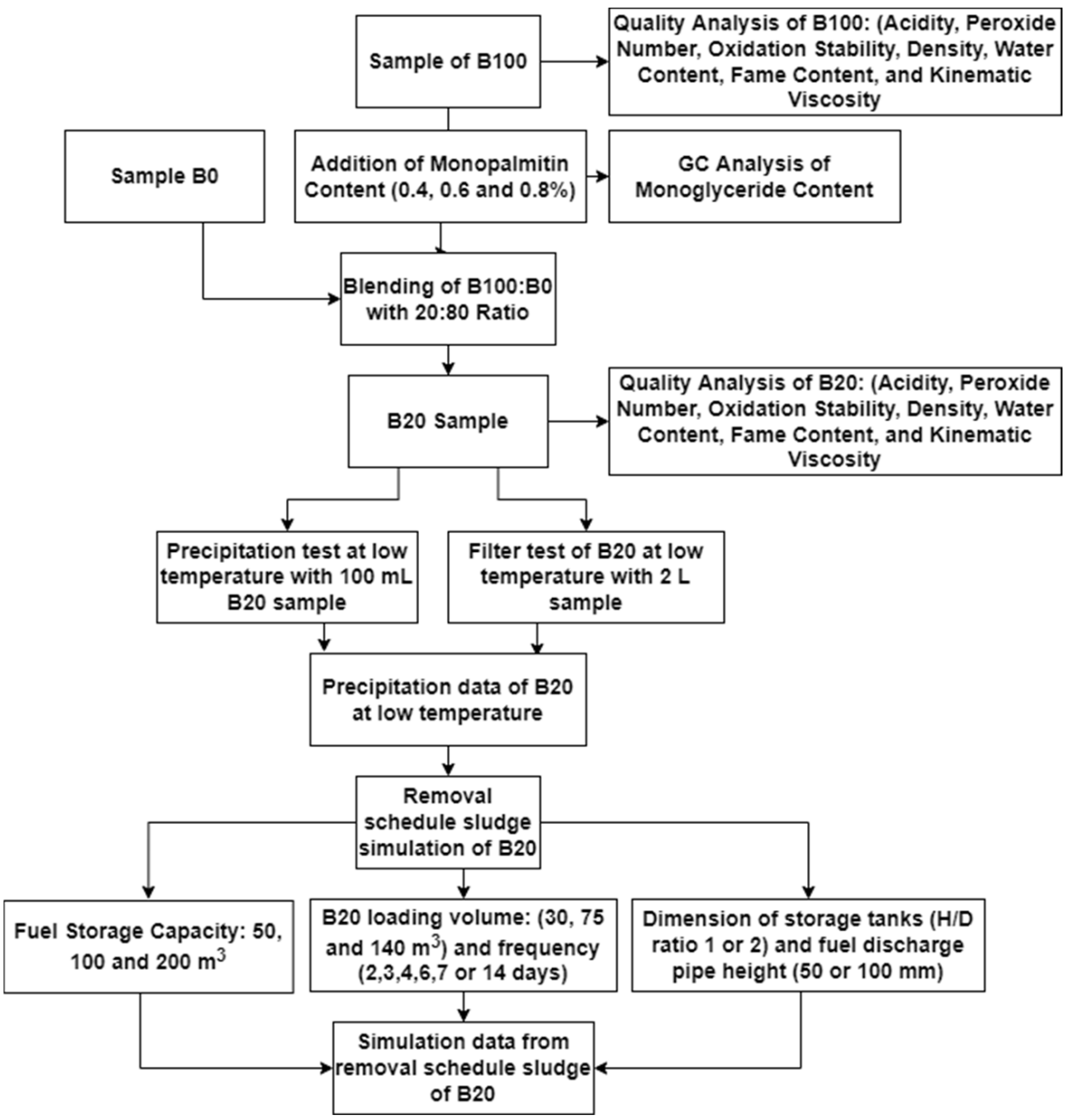

Figure 2. Flowchart for the precipitation tests for sludge removal prediction in the B20 storage tank. 
Table 1. B20 storage tank conditions for simulation of sludge removal schedule from fuel storage tank.

\begin{tabular}{|c|c|c|c|c|c|c|c|c|c|c|}
\hline \multirow[b]{2}{*}{ No. } & \multirow[b]{2}{*}{$\begin{array}{c}\text { Fuel } \\
\text { Storage } \\
\text { Tank }\end{array}$} & \multicolumn{2}{|c|}{ Capacity $\left(\mathrm{m}^{3}\right)$} & \multirow{2}{*}{$\begin{array}{c}\text { Fuel } \\
\text { Loading } \\
\text { Volume } \\
V_{L}\left(\mathrm{~m}^{3}\right)\end{array}$} & \multirow[b]{2}{*}{$\begin{array}{l}\text { Fuel Loading } \\
\text { Frequency } f \\
\text { (days) }\end{array}$} & \multirow[b]{2}{*}{$\begin{array}{c}\text { Tank } \\
\text { Capacity } \\
\left(\mathrm{m}^{4.5}\right)\end{array}$} & \multicolumn{2}{|c|}{ Tank Dimension (mm) } & \multirow[b]{2}{*}{$\begin{array}{c}\text { Ratio } \\
H / D\end{array}$} & \multirow[b]{2}{*}{$\begin{array}{c}\text { Discharge/Outlet } \\
\text { Pipe Height }(h) \\
\text { (mm) }\end{array}$} \\
\hline & & Total $\left(V_{T}\right)$ & $\begin{array}{c}\text { Min } \\
\text { Stock } \\
\left(V_{\text {min }}\right)\end{array}$ & & & & $\begin{array}{l}\text { Diameter } \\
\text { (D) }\end{array}$ & $\begin{array}{l}\text { Height } \\
\text { (H) }\end{array}$ & & \\
\hline 1 & $1 \mathrm{~A}$ & 50 & 20 & 30 & 2 & 55.6 & 4136 & 4136 & 1 & 50 \\
\hline 2 & $1 \mathrm{~B}$ & 50 & 20 & 30 & 4 & 55.6 & 4136 & 4136 & 1 & 50 \\
\hline 3 & $1 \mathrm{C}$ & 50 & 20 & 30 & 4 & 55.6 & 4136 & 4136 & 1 & 100 \\
\hline 4 & $1 \mathrm{D}$ & 50 & 20 & 30 & 4 & 55.6 & 3283 & 6566 & 2 & 50 \\
\hline 5 & $2 \mathrm{~A}$ & 100 & 25 & 75 & 3 & 111.1 & 5211 & 5211 & 1 & 50 \\
\hline 6 & $2 B$ & 100 & 25 & 75 & 6 & 111.1 & 5211 & 5211 & 1 & 50 \\
\hline 7 & $2 \mathrm{C}$ & 100 & 25 & 75 & 6 & 111.1 & 5211 & 5211 & 1 & 100 \\
\hline 8 & $2 \mathrm{D}$ & 100 & 25 & 75 & 6 & 111.1 & 4136 & 8273 & 2 & 50 \\
\hline 9 & $3 \mathrm{~A}$ & 200 & 60 & 140 & 7 & 222.2 & 6566 & 6566 & 1 & 50 \\
\hline 10 & $3 \mathrm{~B}$ & 200 & 60 & 140 & 14 & 222.2 & 6566 & 6566 & 1 & 50 \\
\hline 11 & $3 C$ & 200 & 60 & 140 & 14 & 222.2 & 6566 & 6566 & 1 & 100 \\
\hline 12 & $3 \mathrm{D}$ & 200 & 60 & 140 & 14 & 222.2 & 5211 & 10,423 & 2 & 50 \\
\hline
\end{tabular}

\section{Results}

\subsection{Properties and Modified Monoglyceride Content of Biodiesel}

Table 2 shows several standard parameters of the biodiesel (B100), the petrodiesel (B0), and the blended (B20) fuels. The samples were analyzed according to SNI 7182:2015 [29]. This SNI standard relates to ASTM and EN standards shown in this table.

Table 2. Properties of biodiesel (B100), petrodiesel (B0), and blended (B20) fuels.

\begin{tabular}{ccccccc}
\hline No. & Parameter & B100 & Petrodiesel & B20 & Limit & Methods \\
\hline 1 & Density at $15^{\circ} \mathrm{C}\left(\mathrm{kg} / \mathrm{m}^{3}\right)$ & $855-857$ & $840-844$ & $841-848$ & $815-860$ & ASTM D4052 \\
2 & Kinematic viscosity at $40^{\circ} \mathrm{C}\left(\mathrm{mm}^{2} / \mathrm{s}\right)$ & 4.51 & 2.6 & 2.98 & $2.0-4.5$ & ASTM D445 \\
3 & Cloud point $\left({ }^{\circ} \mathrm{C}\right)$ & $15-16$ & 1.7 & 9.7 & 18 max & ASTM D2500 \\
4 & Ester $(\%$ mass) & $98.7-99.5$ & $<0$ & 20.1 & - & ASTM D7806 \\
5 & Acid number $(\mathrm{mg}$ KOH $/ \mathrm{g})$ & 0.34 & n.a. & 0.089 & 0.6 & ASTM D664 \\
6 & Oxidation stability (hours) & 601 & n.a. & $36.21-36.87$ & 35 & EN 15751 \\
7 & Water content $(\%-$-vol) & $>500$ & n.a. & 249.87 & 500 max & ASTM D6304 \\
8 & Sediment content $(\%$ mass) & $<0$ & n.a. & $<0$ & 0.01 max & ASTM D473 \\
9 & Sulfur $(\%$ mass) & n.a. & 0.106 & n.a. & 0.25 & ASTM D4294 \\
10 & Free glycerol $(\%$ mass) & $0.003-0.006$ & n.a. & n.a. & 0.02 & ASTM D6584 \\
11 & Total glycerol (\% mass) & $0.100-0.128$ & n.a. & n.a. & 0.34 & ASTM D6584 \\
12 & Mono-glyceride (\% mass) & $0.179-0.369$ & n.a. & n.a. & 0.8 & ASTM D6584 \\
\hline
\end{tabular}

n.a. = not available.

Almost all parameters that are not measured (not available $=$ n.a.) were because they do not require measurement because of their nature or because it is very reasonable to assume they have met the standard requirements. The water content parameter is not measured for B100 because it can be estimated that the water content is so high that it is stated as greater than 500 .

The monoglyceride content in the biodiesel sample was varied by adding monopalmitin. Increased monoglyceride (MG) content in B100 (for testing) was made by adding monopalmitin to the biodiesel sample so that its MG content reached $0.4,0.6$, and $0.8 \mathrm{wt} \%$, respectively, before blending. The varied MG samples composition can be shown in Table 3. 
Table 3. Monoglyceride content variation in biodiesel samples.

\begin{tabular}{ccccccc}
\hline No. & Biodiesel & $\begin{array}{c}\text { Added Monopalmitin, } \\
\text { mg/L B100 }\end{array}$ & $\begin{array}{c}\text { Monoglyceride } \\
\text { \%-Mass }\end{array}$ & $\begin{array}{c}\text { Monopalmitin } \\
\text { \%-Mass }\end{array}$ & $\begin{array}{c}\text { Monoolein } \\
\text { \%-Mass }\end{array}$ & $\begin{array}{c}\text { Monostearin } \\
\text { \%-Mass }\end{array}$ \\
\hline 1 & B100-MG initial & - & 0.179 & 0.094 & 0.070 & 0.015 \\
2 & B100-MG 0.4 & 2038.76 & 0.437 & 0.348 & 0.071 & 0.019 \\
3 & B100-MG 0.6 & 3842.97 & 0.623 & 0.533 & 0.071 & 0.019 \\
\hline
\end{tabular}

\subsection{Result of Precipitation Test}

The precipitation test results showed that the precipitation of B20 fuel blended from B100 with various monoglyceride contents has occurred in three different soaking temperatures and an ambient room temperature, as shown in Table 4 . The ratio e:d was used to estimate the accumulated sludge at the bottom layer of the storage tank at a given amount of precipitate from the precipitation test at given soaking temperature conditions.

Table 4. Accumulated precipitate from precipitation tests for B20 fuel blended from B100 with MG $0.179,0.437$, and $0.623 \%$-mass and B20 fuel from market (fuel station).

\begin{tabular}{|c|c|c|c|c|c|}
\hline \multirow{3}{*}{ No. } & \multirow{3}{*}{$\begin{array}{c}\text { Soaking } \\
\text { Temperatures }\left({ }^{\circ} \mathrm{C}\right)\end{array}$} & \multicolumn{3}{|c|}{ Sample B20 Blended from B100 with $0.179 \%$ MG } & \multirow{3}{*}{ Ratio $=\mathrm{e}: \mathrm{d}$} \\
\hline & & \multicolumn{2}{|c|}{ The Precipitate from Precipitation Test, g/L } & \multirow{2}{*}{$\begin{array}{l}\text { Estimated Accumulated } \\
\text { Precipitate, g/L }\end{array}$} & \\
\hline & & In $100 \mathrm{~mL}$ & In 2 Liters & & \\
\hline a & $\mathrm{b}$ & c & $\mathrm{d}$ & e & $\mathrm{f}$ \\
\hline 1 & $\begin{array}{l}\text { 24-30 (room } \\
\text { temperatures) }\end{array}$ & 0.012 & 0.012 & 0.016 & 1.3 \\
\hline 2 & 25 & 0.013 & 0.014 & 0.018 & 1.3 \\
\hline 3 & 20 & 0.013 & 0.012 & 0.016 & 1.3 \\
\hline \multirow[t]{2}{*}{4} & 15 & 0.015 & 0.015 & 0.021 & 1.4 \\
\hline & \multirow{3}{*}{$\begin{array}{c}\text { Soaking } \\
\text { Temperatures }\left({ }^{\circ} \mathrm{C}\right)\end{array}$} & \multicolumn{3}{|c|}{ Sample B20 blended from B100 with $0.437 \%$ MG } & \multirow{3}{*}{ Ratio = e: $\mathrm{d}$} \\
\hline \multirow[t]{2}{*}{ No. } & & Precipitate fro & ation Test, g/L & \multirow{2}{*}{$\begin{array}{l}\text { Estimated Accumulated } \\
\text { Precipitate, g/L }\end{array}$} & \\
\hline & & in $100 \mathrm{~mL}$ & in 2 Liters & & \\
\hline a & $\mathrm{b}$ & c & $\mathrm{d}$ & e & $\mathrm{f}$ \\
\hline 1 & $\begin{array}{l}\text { 24-30 (room } \\
\text { temperatures) }\end{array}$ & 0.021 & 0.016 & 0.019 & 1.2 \\
\hline 2 & 25 & 0.070 & 0.031 & 0.090 & 2.9 \\
\hline 3 & 20 & 0.120 & 0.054 & 0.187 & 3.5 \\
\hline 4 & 15 & 0.162 & 0.145 & 0.368 & 2.5 \\
\hline \multirow{3}{*}{ No. } & \multirow{3}{*}{$\begin{array}{c}\text { Soaking } \\
\text { Temperatures }\left({ }^{\circ} \mathrm{C}\right)\end{array}$} & \multicolumn{3}{|c|}{ Sample B20 blended from B100 with $0.623 \%$ MG } & \multirow{3}{*}{ Ratio = e:d } \\
\hline & & \multicolumn{2}{|c|}{ Precipitate from Precipitation Test, g/L } & \multirow{2}{*}{$\begin{array}{l}\text { Estimated Accumulated } \\
\text { Precipitate, g/L }\end{array}$} & \\
\hline & & in $100 \mathrm{~mL}$ & in 2 Liters & & \\
\hline a & $\mathrm{b}$ & c & $\mathrm{d}$ & $\mathrm{e}$ & $\mathrm{f}$ \\
\hline 1 & $\begin{array}{l}\text { 24-30 (room } \\
\text { temperatures) }\end{array}$ & 0.102 & 0.120 & 0.850 & 7.1 \\
\hline 2 & 25 & 0.148 & 0.125 & 1.180 & 9.4 \\
\hline 3 & 20 & 0.262 & 0.285 & 2.150 & 7.5 \\
\hline 4 & 15 & 0.308 & 0.305 & 2.170 & 7.1 \\
\hline
\end{tabular}


Table 4. Cont.

\begin{tabular}{|c|c|c|c|c|c|}
\hline \multirow{3}{*}{ No. } & \multirow{3}{*}{$\begin{array}{c}\text { Soaking } \\
\text { Temperatures }\left({ }^{\circ} \mathrm{C}\right)\end{array}$} & \multicolumn{3}{|c|}{ Sample B20 (Biosolar) from Market (Fuel Station) } & \multirow{3}{*}{ Ratio = e: $\mathrm{d}$} \\
\hline & & \multicolumn{2}{|c|}{ Precipitate from Precipitation Test, g/L } & \multirow{2}{*}{$\begin{array}{l}\text { Estimated Accumulated } \\
\text { Precipitate, g/L }\end{array}$} & \\
\hline & & in $100 \mathrm{~mL}$ & in 2 Liters & & \\
\hline $\mathrm{a}$ & $\mathrm{b}$ & c & $\mathrm{d}$ & e & $\mathrm{f}$ \\
\hline 1 & $\begin{array}{l}\text { 24-30 (room } \\
\text { temperatures) }\end{array}$ & 0.099 & 0.078 & 0.794 & 10.2 \\
\hline 2 & 25 & 0.120 & 0.138 & 1.180 & 8.6 \\
\hline 3 & 20 & 0.234 & 0.246 & 1.981 & 8.1 \\
\hline 4 & 15 & 0.218 & 0.258 & 2.201 & 8.5 \\
\hline
\end{tabular}

Figure $3 a-c$ simulates the removal schedule of sludge accumulated from B20 fuel using B100 with a monoglyceride content of $0.437 \%$-mass in different tank storage volumes.

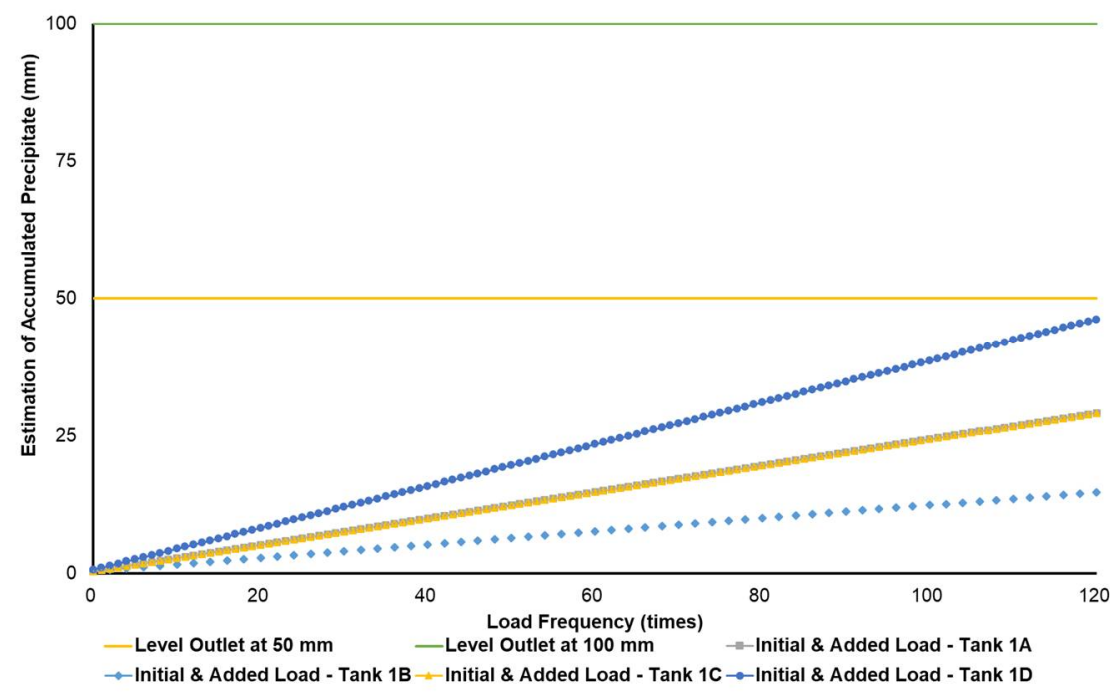

(a)

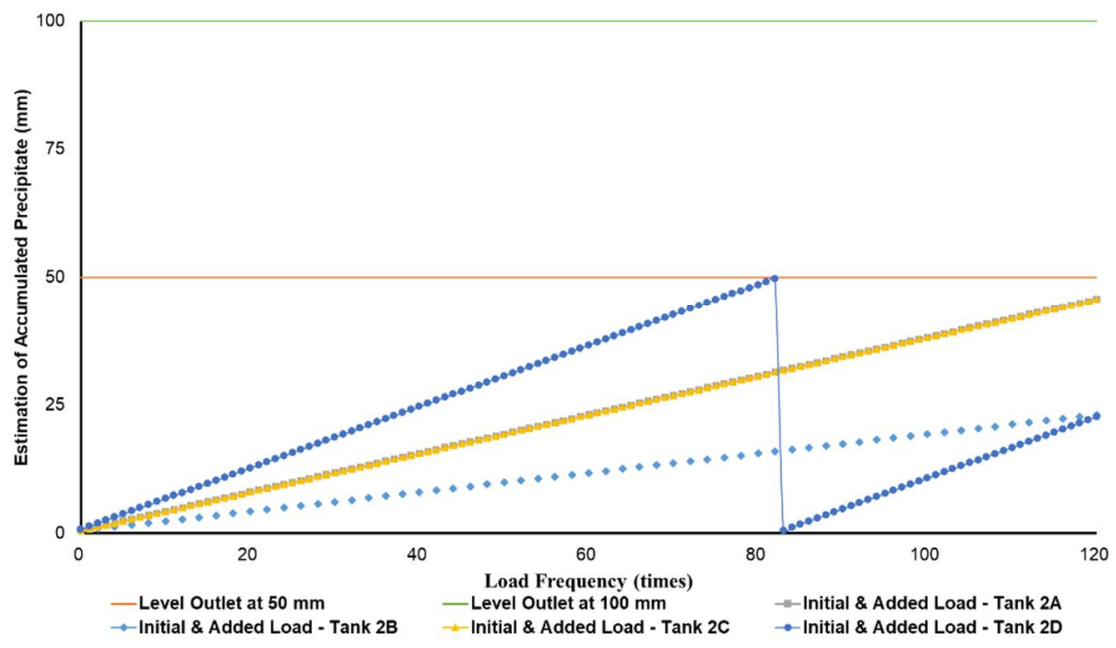

(b)

Figure 3. Cont. 


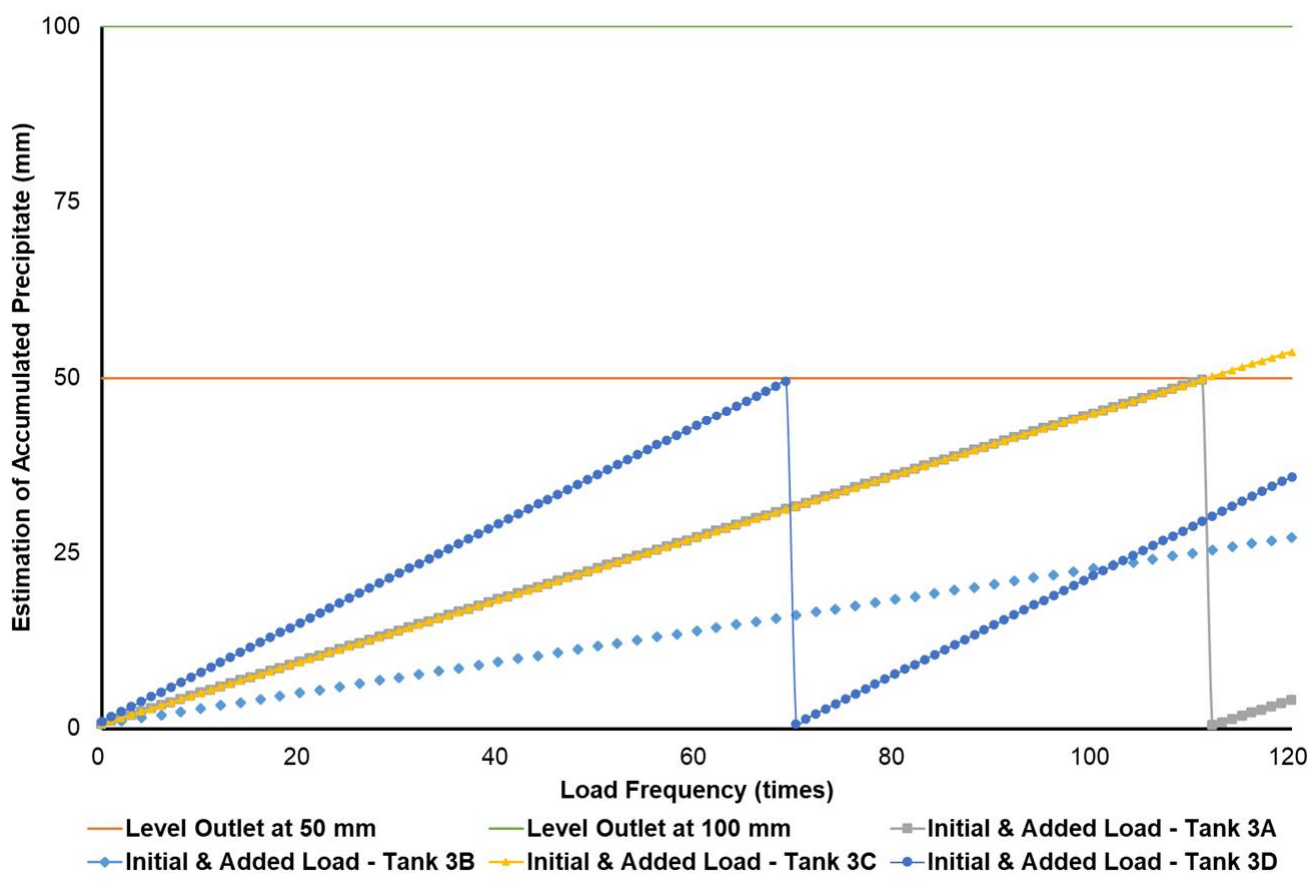

(c)

Figure 3. Schedule simulation for sludge removal from the storage tank of B20 fuel blended from B100 with monoglyceride content of $0.437 \%$-mass. The tank volume is (a) 50, (b) 100, and (c) $200 \mathrm{~m}^{3}$.

Figure 4a-c simulates the removal schedule of sludge accumulated from B20 fuel using B100 with a monoglyceride content of $0.623 \%$-mass in different tank storage volumes.

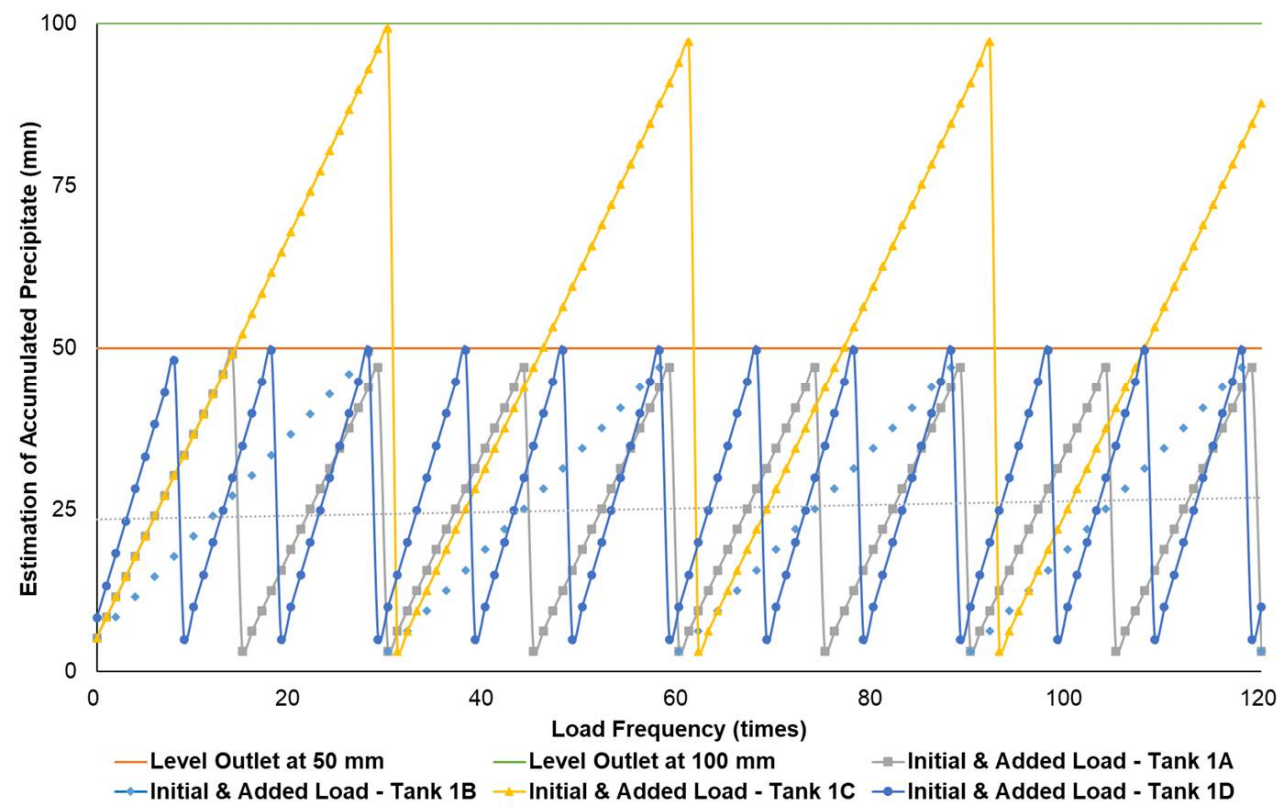

(a)

Figure 4. Cont. 


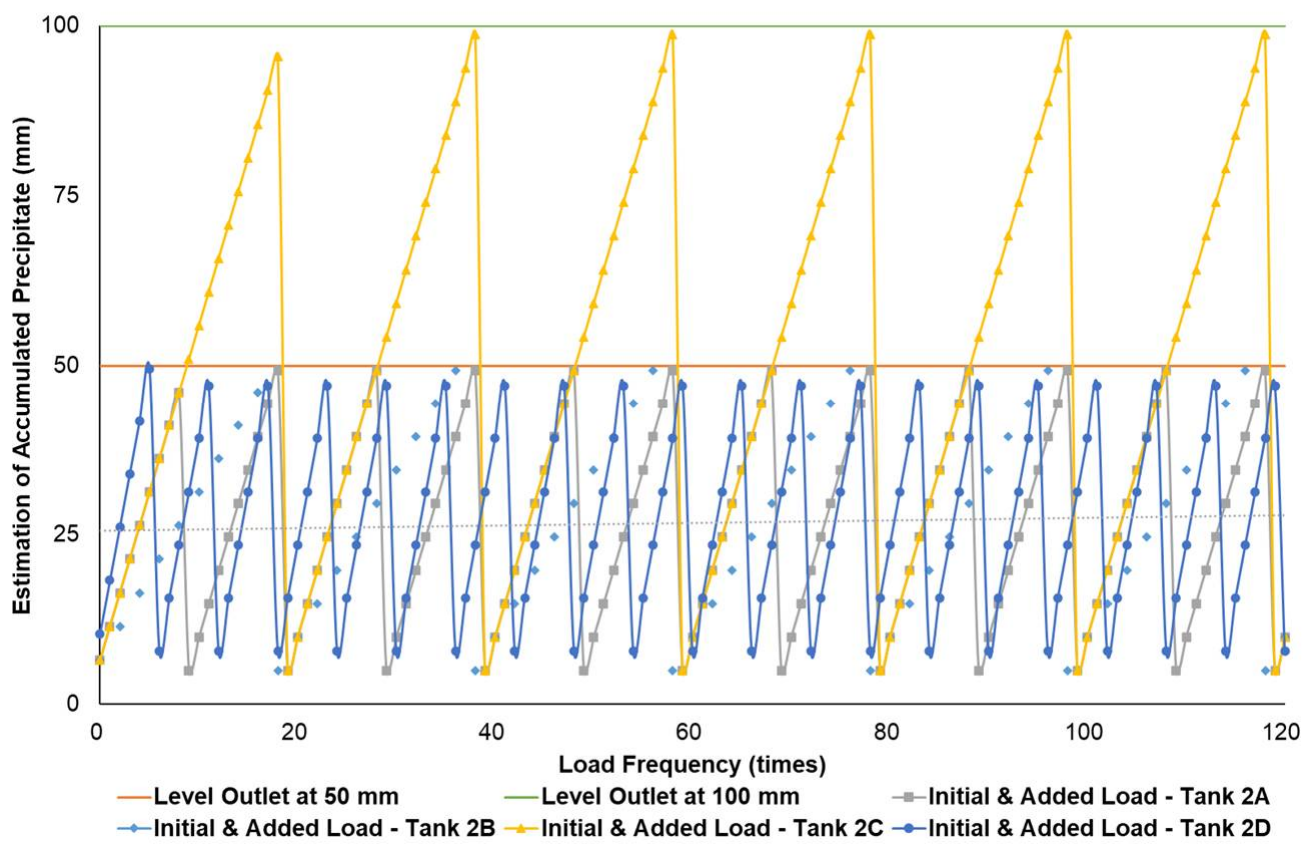

(b)

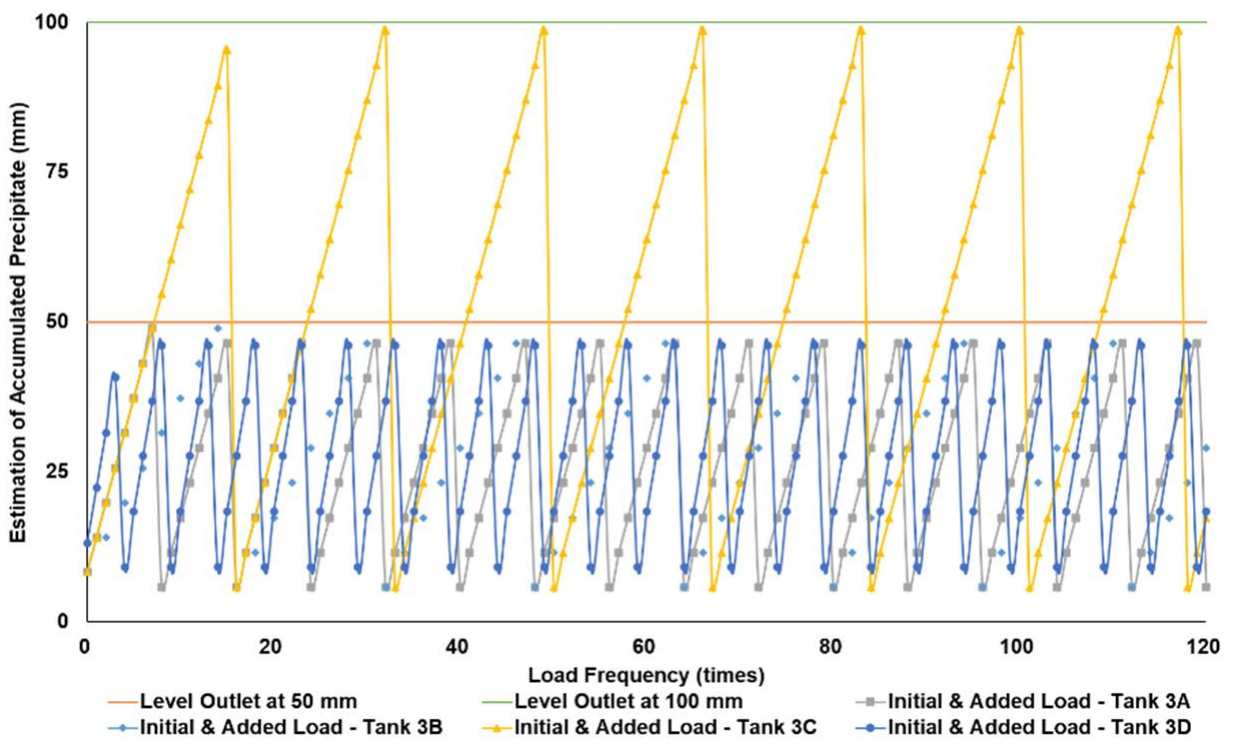

(c)

Figure 4. Schedule simulation for sludge removal from the storage tank of B20 fuel blended from B100 with monoglyceride content of $0.623 \%$-mass. The tank volume is (a) 50, (b) 100, and (c) $200 \mathrm{~m}^{3}$.

Figure $5 \mathrm{a}-\mathrm{c}$ simulates the removal schedule of sludge accumulated from B20 fuel obtained from the market in different tank storage volumes. 


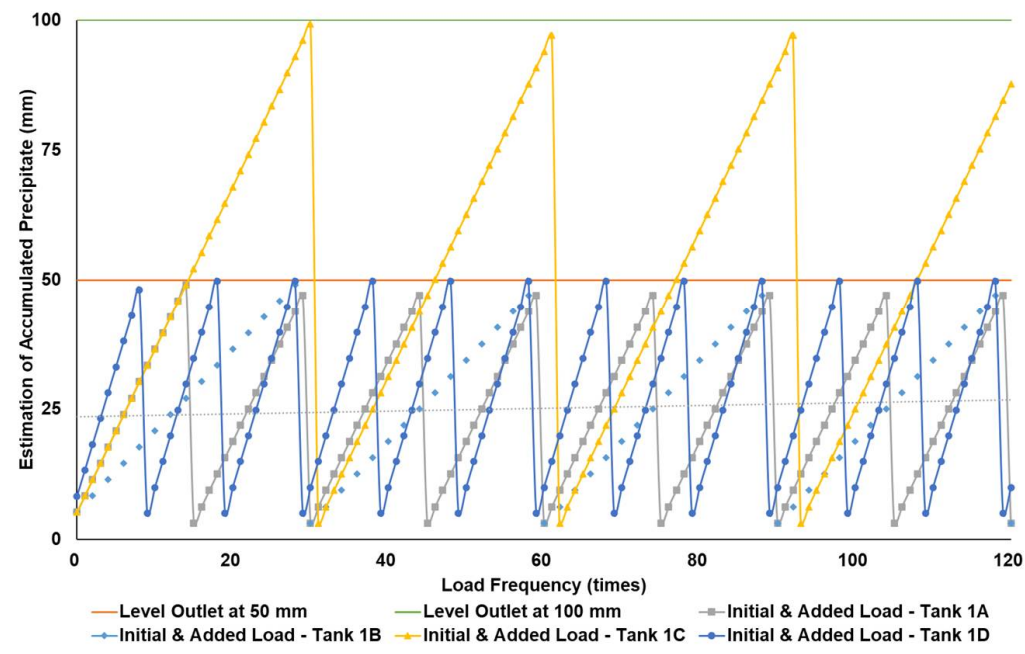

(a)

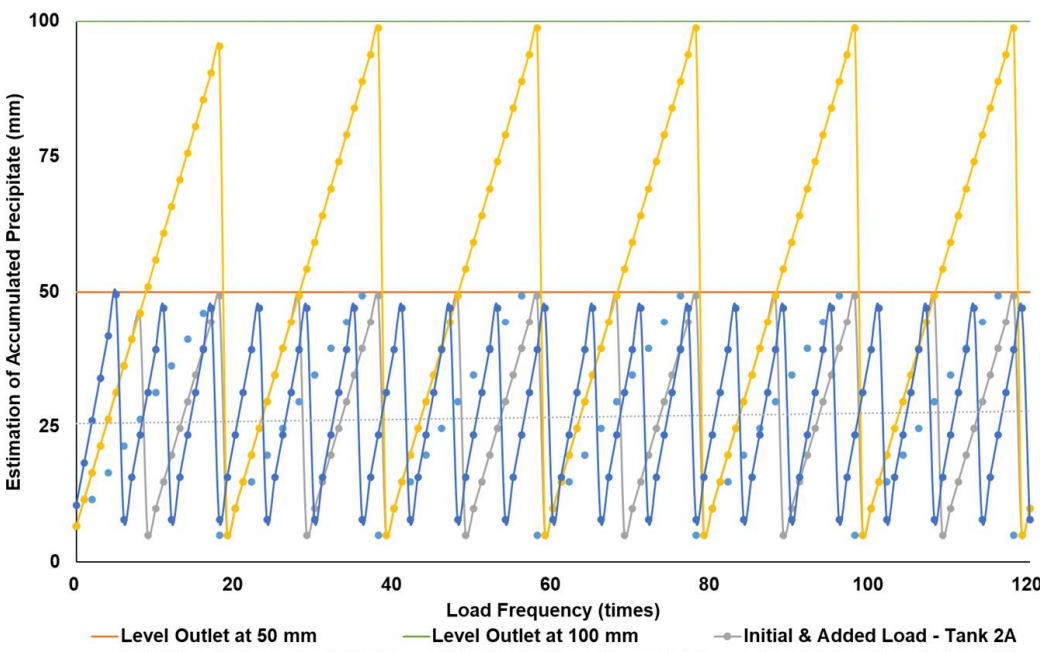

(b)

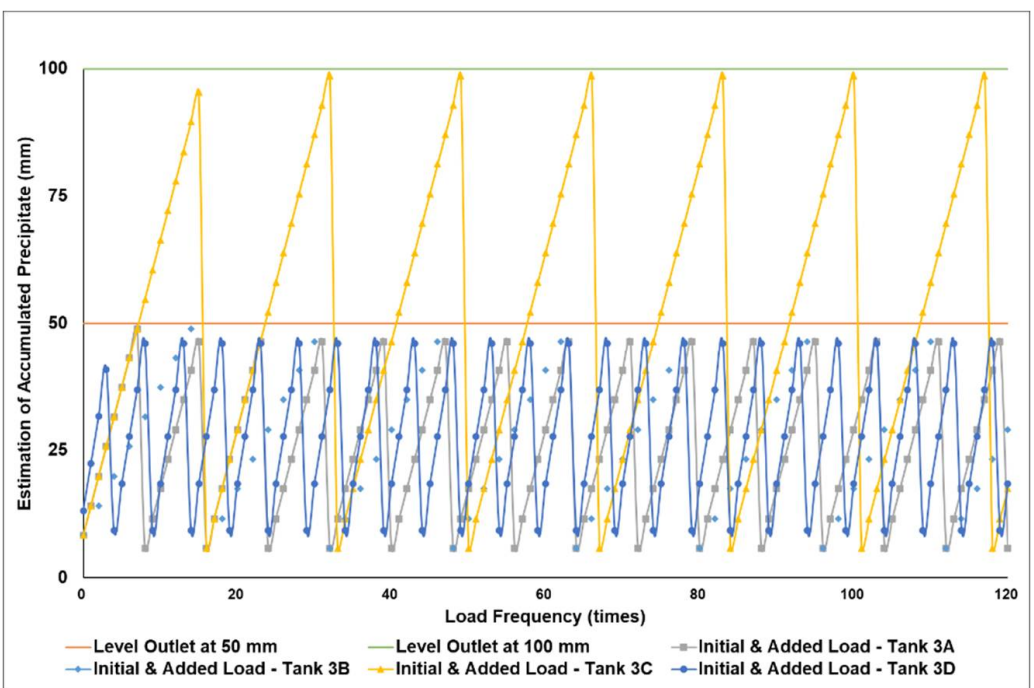

(c)

Figure 5. Schedule simulation for sludge removal from the storage tank of B20 fuel from the market. The tank volume is (a) 50, (b) 100, and (c) $200 \mathrm{~m}^{3}$. 
Figures 3-5 show a very clear difference in the accumulation of B20 storage tanks containing different MGs. The horizontal lines at the 50- and $100-\mathrm{mm}$ points indicate the outlet levels. After reaching the two outlet setting levels, the loading curve returns to its lowest point due to sludge removal. The cycle of accumulation of precipitation will repeat itself.

\section{Discussion}

The analysis data of biodiesel quality were found to be within biodiesel quality standards according to SNI 7182:2015 and ASTM D6571 specifications, and each corresponding BXX parameter standard stated in ASTM. The original monoglyceride content in biodiesel before adding monopalmitin was analyzed to be $0.179 \%$-mass (Table 2 ), containing $0.094 \%$-mass monopalmitin, $0.070 \%$-mass monoolein, and $0.015 \%$-mass monostearin (Table 3). Monoolein is categorized as an unsaturated monoglyceride, whereas monopalmitin and monostearin are saturated monoglycerides. To affect precipitate formation in BXX fuel, monopalmitin was added to biodiesel to vary monoglyceride content in biodiesel samples. The modified monoglyceride content of biodiesel samples became $0.437 \%$ and $0.623 \%$, as shown in Table 3 . By adding monopalmitin to vary the monoglyceride content in biodiesel, the percentage of saturated monoglyceride (SMG) composition-i.e., monopalmitin and monostearin - has changed from the initial percentage of $60.9 \%$-mass to 83.8 and $88.6 \%$-mass, respectively.

The ratio between the amount of collected precipitate at the bottom layer of the 2-liter measuring cylinder and the total amount of collected precipitate for the 2-liter measuring cylinder was calculated to estimate the accumulated sludge of B20 fuel. The level of accumulated sludge at the bottom layer of the storage tank depends on the amount of precipitate from the precipitation test and the loading volume and frequency of B20 fuel into the storage tank. Loading 'fresh' B20 fuel into the storage tank adds the amount of the precipitate/sludge to the existing sludge that has already settled down at the bottom layer of the tank. Therefore, removing the accumulated sludge is necessary when the sludge level has reached the level of the B20 discharge pipe in the storage tank. Hence, information regarding the loading volume and frequency of B20 fuel into the storage tank, the tank volume capacity, and the level of the B20 discharge pipe in the storage tank was needed to estimate the schedule of the sludge removal from the storage tank.

The lower soaking temperature conditions of B20 caused a higher amount of precipitate, and higher monoglyceride contents produced higher amounts of precipitate. This result confirmed the previous results [21-26]. The higher monoglyceride content could trigger more precipitate formation, which could accumulate at the bottom layer of the storage tank. The result shown in Table 4 explained that the estimated accumulated precipitate of B20 fuel blended from B100 with a monoglyceride content of $0.623 \%$-mass was the highest compared to those with monoglyceride content $0.437 \%$-mass or $0.179 \%$-mass. This further affected the ratio between the amount of collected accumulated precipitate at the bottom layer of the 2-liter measuring cylinder and the total amount of collected precipitate for the 2-liter measuring cylinder. These precipitate ratio values for varied monoglyceride content of $0.179,0.437$, and $623 \%$-mass were calculated to be about 1.3-1.4, 1.2-3.5, and 7.1-9.4, respectively. The ratio value of the precipitate for the B20 fuel sample from the market was about $8.1-10.2$. This value was close to that for monoglyceride content of $0.623 \%$-mass. This value indicates that the B20 fuel sample from the market may be produced from B100 having monoglyceride content close to $0.623 \%$-mass.

For the data given in Table 1 and Figure 1, specifications of B20 storage tanks were varied in their volume capacities (VT), dimensions (H/D ratios), and discharge piping level (h) in the storage tank. The precipitation results of B20 samples from B100 having monoglyceride content of 0.437 and $0.623 \%$-mass and B20 samples from the market were further used to estimate the schedule for sludge removal from the B20 storage tank. Figure 3a-c explained the removal schedule of sludge accumulated from B20 fuel using B100 with a monoglyceride content of $0.437 \%$-mass. These figures illustrated that the frequency of 
sludge removal was predicted not so often for all capacities of storage tanks. The tank's bottom layer has not yet reached the level of the fuel discharge pipe for many instances of 'fresh' B20 fuel being loaded into the tanks.

Different results were found when B20 fuel from B100 had a monoglyceride content of $0.623 \%$-mass and B20 fuel sample from the market, as in Figures $3 a-c$ and $4 a-c$. Before reaching the fuel discharge piping outlet level, the sludge removal should be done more often than in Figure 2. The lower the fuel discharge piping outlet level was placed, the more often the sludge should be discharged from the tank's bottom layer, shown in Figures 3 and 4 for Tanks 1B and 1C, Tanks 2B and 2C, and Tanks 3B and 3C. For the same tank capacities and levels of fuel discharge piping outlet, the higher the H/D ratios of the tanks were set, the more often the sludge should be discharged from the bottom layer of the tank, shown in Figures 3 and 4 for Tanks 1A and 1D, Tanks 2A and 2D, and Tanks 3A and 3D. The longer diameter of the tank could provide the space for the accumulated sludge to settle down at the bottom layer of the tank, and therefore, more time was needed to reach the level of fuel discharge piping outlet. This explanation could also be relevant when the horizontal fuel storage tank was used. The other factor that could affect the schedule of sludge removal from the fuel storage tank was the amount and frequency of 'fresh' B20 fuel loaded into the tanks. The more often the 'fresh' B20 fuel was loaded into the tank, the more likely sludge removal could be done more often.

\section{Conclusions}

The precipitation test result for B20 fuel, blended from biodiesel with various monoglyceride content stored for 21 days at varied soaking temperature conditions, were used to estimate accumulated precipitate (sludge) at the bottom layer of the fuel storage tank. From the simulation exercise, it was found that the schedule of sludge removal from the B20 storage tank will depend on the monoglyceride content in biodiesel, the volume capacity and dimensions of the storage tank, loading volume of 'fresh' B20 fuel into the storage tank, and the piping level of discharged fuel pumped to the daily fuel tank or fuel dispenser. The lower the fuel discharge piping outlet level, the more often sludge should be discharged from the tank's bottom layer. The higher the H/D ratios of the tanks were set, the more often the sludge should be discharged from the bottom layer of the tank. The more often 'fresh' B20 fuel was loaded into the tank, the more sludge removal should be done.

Author Contributions: Conceptualization, M.G. and H.H.; methodology, M.G., M.S. and T.P.; software, I.P.; validation, E.R., M.K.A. and P.C.; formal analysis, I.P.; experiments, I.P.; resources, I.P. and A.D.A.; data curation, I.P.; writing-original draft preparation, I.P.; writing-review and editing, M.A.D. and M.G.; supervision, M.G. All authors have read and agreed to the published version of the manuscript.

Funding: This research was funded by Universitas Indonesia through the scheme of Hibah Riset Kolaborasi Internasional WCU 2021 (NKB-643/UN2.RST/HKP.05.00/2021). The Ministry of Research and Higher Education of Indonesia's financial support through the research grant "Hibah Penelitian Dasar Unggulan Perguruan Tinggi" (PDUPT) 2021 (NKB-204/UN2.RST/HKP.05.00/2021).

Institutional Review Board Statement: Not applicable.

Informed Consent Statement: Not applicable.

Data Availability Statement: The data presented in this study are available on request from the corresponding author. The data are not publicly available due to official policy/aggreement between our campuses and research centre.

Acknowledgments: The authors gratefully acknowledged the financial support by Universitas Indonesia through the scheme of Hibah Riset Kolaborasi Internasional WCU 2021 (NKB-643/UN2.RST/ HKP.05.00/2021).

Conflicts of Interest: The authors declare no conflict of interest. 


\section{References}

1. Knothe, G.; Steidley, K.R. Kinematic viscosity of biodiesel fuel components and related compounds. Influence of compound structure and comparison to petrodiesel fuel components. Fuel 2005, 84, 1059-1065. [CrossRef]

2. Mittlebach, M.; Remschmidt, C. Biodiesel: The Comprehensive Handbook; Boersedruck Ges. MBH: Viena, Austria, 2004.

3. Knothe, G.; Van Gerpen, J.H.; Krahl, J. The Biodiesel Handbook; AOCS Press: Champaign, IL, USA, 2005.

4. Hoekman, S.K.; Broch, A.; Robbins, C.; Ceniceros, E.; Natarajan, M. Review of biodiesel composition, properties, and specifications. Renew. Sustain. Energy Rev. 2012, 16, 143-169. [CrossRef]

5. Dunn, R.O. Effects of minor constituents on cold flow properties and performance of biodiesel. Prog. Energy Combust. Sci. 2009, 35, 481-489. [CrossRef]

6. Thangamani, S.; Sundaresan, S.N.; Kannappan, S.S.; Barawkar, V.T.; Jeyaseelan, T. Impact of biodiesel and diesel blends on the fuel filter: A combined experimental and simulation study. Energy 2021, 227, 120526. [CrossRef]

7. Chupka, G.M.; Fouts, L.; McCormick, R.L. Effect of low-level impurities on low-temperature performance properties of biodiesel. Energy Environ. Sci. 2012, 5, 8734-8742. [CrossRef]

8. Na-Ranong, D.; Kitchaiya, P. Precipitation above cloud point in palm oil based biodiesel during production and storage. Fuel 2014, 122, 287-293. [CrossRef]

9. Tang, H.; Salley, S.O.; Ng, K.S. Fuel properties and precipitate formation at low temperature in soy-, cottonseed-, and poultry fat-based biodiesel blends. Fuel 2008, 87, 3006-3017. [CrossRef]

10. Tang, H.; De Guzman, R.C.; Salley, S.O.; Simon Ng, K.Y. Formation of insolubles in palm oil-, yellow grease-, and soybean oil-based biodiesel blends after cold soaking at $4{ }^{\circ} \mathrm{C}$. J. Am. Oil Chem. Soc. 2008, 85, 1173-1182. [CrossRef]

11. Joshi, R.M.; Pegg, M.J. Flow properties of biodiesel fuel blends at low temperatures. Fuel 2007, 86, 143-151. [CrossRef]

12. Soriano, N.U.; Migo, V.P.; Matsumura, M. Ozonized vegetable oil as pour point depressant for neat biodiesel. Fuel 2006, 85, 25-31. [CrossRef]

13. Soriano, N.U.; Migo, V.P.; Sato, K.; Matsumura, M. Crystallization behaviour of neat biodiesel and biodiesel treated with ozonized vegetable oil. Eur. J. Lipid Sci. 2005, 107, 689-696. [CrossRef]

14. Alleman, T.L.; McCormick, R.L.; Christensen, E.D.; Fioroni, G.; Moriarty, K.; Yanowitz, J. 2016 Biodiesel Handling and Use Guide; US Department of Energy: Washington, DC, USA, 2016.

15. Plata, V.; Gauthier-Maradei, P.; Kafarov, V. Influence of minor components on precipitate formation and filterability of palm oil biodiesel. Fuel 2015, 144, 130-136. [CrossRef]

16. Alves-Fortunato, M.; Ayoub, E.; Bacha, K.; Mouret, A.; Dalmazzone, C. Fatty Acids Methyl Esters (FAME) autoxidation: New insights on insoluble deposit formation process in biofuels. Fuel 2020, 268, 117074. [CrossRef]

17. ASTM D 7501-12a; Standard Test Method for Determination of Fuel Filter Blocking Potential of Biodiesel (B100) Blend Stock by Cold Soak Filtration Test (CSFT); ASTM International: Philadelphia, PA, USA, 2012.

18. Lin, H.; Haagenson, D.M.; Wiesenborn, D.P.; Pryor, S.W.; Brudvik, R. Effect of Trace Contaminants on Cold Soak Filterability of Canola Biodiesel. In 2010 Pittsburgh, Pennsylvania, June 20-June 23, 2010; American Society of Agricultural and Biological Engineers: St. Joseph, MI, USA, 2010; Volume 90, pp. 1771-1777. [CrossRef]

19. ASTM D 2068-10; Determination of Filter Blocking Tendency (FBT). ASTM International: Philadelphia, PA, USA, 2010.

20. IP 3872939444; Determination of Filter Blocking Tendency. Energy Institute Publication: London, UK, 2017.

21. Girry, I.P.; Paryanto, I.; Prakoso, T.; Gozan, M. Effect of monopalmitin content and temperature on precipitation rate in biodieselpetroleum diesel blends. In E3S Web of Conferences_CSSPO; EDP Sciences: Les Ulis, France, 2018; Volume 52, p. 00021.

22. Ghaizani, M.A.; Abdurrosyid, I.; Paryanto, I.; Gozan, M. Monostearin effects on the formation of precipitate in palm oil biodiesel and petroleum diesel blends with various storage temperature. In E3S Web of Conferences_CSSPO; EDP Sciences: Les Ulis, France, 2018; Volume 52, p. 00026.

23. Paryanto, I.; Prakoso, T.; Susanto, H.B.; Gozan, M. The Effect of Outdoor Temperature Conditions and Monoglyceride Content on the Precipitate Formation of Biodiesel-Petrodiesel Blended Fuel (BXX). Evergreen 2019, 6, 59-64. [CrossRef]

24. Paryanto, I.; Prakoso, T.; Suyono, E.A.; Gozan, M. Determination of the upper limit of monoglyceride content in biodiesel for B30 implementation based on the measurement of the precipitate in a Biodiesel-Petrodiesel fuel blend (BXX). Fuel 2019, $258,116104$. [CrossRef]

25. Mansur, D.; Fitriady, M.A.; Setiapraja, H.; Paryanto, I.; Haspriyanti, N.; Dela, N.; Gozan, M. Precipitation Study of B30 Blended from FAME and/or HVO and Petro Diesel Fuel. In SAE Technical Paper Series; SAE International: Warrendale, PA, USA, 2019.

26. Paryanto, I.; Rismana, E.; Arbianto, A.; Prakoso, T.; Gozan, M. The Effect of Fuel Filter Pore Size on B20 Fuel Filter Clogging at Low-Temperature Condition. IOP Conf. Ser. Earth Environ. Sci. 2020, 520, 012002. [CrossRef]

27. Economic Research Institute for ASEAN and East Asia (ERIA). Study of Renewable Energy Potential and Its Effective Usage in East Asia Summit Countries; ERIA Project Report 2017 No.17; Economic Research Institute for ASEAN and East Asia (ERIA): Jakarta, Indonesia, 2017.

28. Ministry of Energy and Mineral Resources (MEMR), Indonesia. MEMR Regulation No. 12/2015 about Supply, Utilization and Commerce of Biofuel; Ministry of Energy and Mineral Resources (MEMR): Jakarta, Indonesia, 2015.

29. Ministry of Energy and Mineral Resources (MEMR), Indonesia. Report of Assessment and Testing of B20 Utilization (B20 Road Test); Ministry of Energy and Mineral Resources (MEMR): Jakarta, Indonesia, 2015. 
30. SNI 7182-2015; Indonesia National Biodiesel Standard. Badan Standardisasi Nasional (BSN): Jakarta, Indonesia, 2015.

31. ASTM D 6584-00; Determination of Free and Total Glycerin in B-100 Biodiesel Methyl Esters by Gas Chromatography. ASTM International: Philadelphia, PA, USA, 2000. 